\title{
The gastrointestinal frontier: IgA and viruses
}

\section{Sarah E. Blutt and Margaret E. Conner*}

Department of Molecular Virology and Microbiology, Baylor College of Medicine, Houston, TX, USA

\section{Edited by:}

Nils Yngve Lycke, University of Gothenburg, Sweden

\section{Reviewed by:}

Artur Summerfield, Institute of Virology and Immunoprophylaxis, Switzerland

Nicolaas Adrianus Bos, University

Medical Center Groningen,

Netherlands

\section{*Correspondence.}

Margaret E. Conner, Department of Molecular Virology and Microbiology, Baylor College of Medicine, Room 936E, One Baylor Plaza, MSC BCM 385, Houston, TX 77030, USA

e-mail: mconner@bcm.edu
Viral gastroenteritis is one of the leading causes of diseases that kill $\sim 2.2$ million people worldwide each year. IgA is one of the major immune effector products present in the gastrointestinal tract yet its importance in protection against gastrointestinal viral infections has been difficult to prove. In part this has been due to a lack of small and large animal models in which pathogenesis of and immunity to gastrointestinal viral infections is similar to that in humans. Much of what we have learned about the role of IgA in the intestinal immune response has been obtained from experimental animal models of rotavirus infection. Rotavirus-specific intestinal IgA appears to be one of the principle effectors of long term protection against rotavirus infection. Thus, there has been a focus on understanding the immunological pathways through which this virus-specific IgA is induced during infection. In addition, the experimental animal models of rotavirus infection provide excellent systems in which new areas of research on viral-specific intestinal IgA including the long term maintenance of viral-specific $\lg A$.

Keywords: IgA, rotavirus, calicivirus, norovirus, adenovirus, astrovirus, small intestine, gastrointestinal virus

\section{INTRODUCTION}

Gastrointestinal infections kill about 2.2 million people each year worldwide (1). In the United States, between 60 and 70 million are affected annually with gastrointestinal diseases (2) and viral gastroenteritis ranks among the top 15 principal discharge diagnoses from hospital admissions (3). Viral infections of the gastrointestinal tract are divided into two broad categories based on whether infection results in disease there (enteropathogenic) or elsewhere (non-enteropathogenic). Classical enteropathogenic viruses actually infect cells that comprise the gastrointestinal system resulting in gastrointestinal disease symptoms such as vomiting, diarrhea, malabsorption, and pain. The majority of viral gastrointestinal illnesses are caused by rotavirus, norovirus, adenovirus, and astrovirus. By contrast, although non-enteropathogenic viruses enter the body via the gastrointestinal tract, they cause mild to no gastrointestinal disease because they are distributed systemically and cause disease in other organ systems. Examples of important human non-enteropathogenic viruses include polio virus, coxsackievirus, echovirus, and hepatitis A virus. Although not a perfect fit in either category, HIV can enter through the lower gastrointestinal tract and can be associated with mild gastrointestinal disease. HIV infects cells of the immune system both in the gastrointestinal tract and systemically and thus its most severe effects are on the immune system. Both enteropathogenic and non-enteropathogenic gastrointestinal viruses induce IgA that functions in protective immunity. This review will focus on enteropathogenic gastrointestinal virus infections highlighting rotavirus, since much has been learned from the experimental animal models. The role that gastrointestinal IgA plays in protective immunity and the mechanisms through which intestinal IgA is induced will be discussed. Emerging areas in IgA research during viral gastrointestinal infections will be explored.
IgA AND IgA DEFICIENCY IN THE GASTROINTESTINAL TRACT IgA is one of the main effector molecules produced by initiation of immune responses in the gastrointestinal tract. IgA is predominant in the intestinal lumen and it is synthesized in quantities that far exceed any of the other antibodies (4). Despite high levels of IgA in the gastrointestinal tract, its importance in intestinal immunity to pathogens has been difficult to prove. IgA clearly functions in binding to antigens, toxins, foreign proteins, and microorganisms to inhibit penetration of the intestinal epithelium (5-11). Intestinal IgA is also critical for regulation of commensal bacterial populations (12) and in its absence these populations expand, eventually escaping the gastrointestinal tract, resulting in both local and systemic activation of the immune system (12-14). By containing and controlling the microorganism population, IgA prevents their access to the intestinal immune system and thus functions to reduce local inflammation induced by endogenous bacteria (15).

IgA deficiency is the most common primary immunodeficiency although incidence depends on genetic background (16). IgA deficiency ranges from 1:223 to 1:1000 in community studies and from 1:400 to $1: 3000$ in healthy blood donors (17-19). Selective IgA deficiency is defined by serum levels of IgA below $0.05 \mathrm{~g} / \mathrm{L}(19,20)$. Low levels of IgA have been associated with a range of clinical manifestations including increased incidence of gastrointestinal diseases such as giardiasis, malabsorption, lactose intolerance, celiac disease, ulcerative colitis, lymphoid hyperplasia, and malignant proliferation (21-24). Patients with IgA deficiency suffer from an increased incidence of gastrointestinal infections and multiple bouts of diarrhea compared to IgA normal individuals (25-27). Despite these general statements, there are no well controlled studies that address the question of whether or not IgA deficiency predisposes individuals to increased susceptibility to 
and recurrence of gastrointestinal viral infections. In fact, it is estimated that $85-90 \%$ of IgA-deficient individuals are asymptomatic (25). One explanation might be that individuals with low levels of serum IgA may actually have sufficient secretory IgA at their mucosal surfaces to remain asymptomatic $(28,29)$. Another might be that other antibody isotypes, in particular $\operatorname{IgM}$, via transport to the mucosal surface, compensates for the loss of IgA (30-32).

\section{IgA AND PROTECTIVE IMMUNITY AGAINST GASTROINTESTINAL VIRAL INFECTIONS}

Since IgA is produced in large quantities at mucosal surfaces including the gastrointestinal tract, it has long been presumed that $\operatorname{IgA}$ is a critical factor in protection of these surfaces against viral infections. Many studies in humans correlate increases in viral-specific IgA levels at the mucosal surface with either the cessation of virus excretion or protection against infection and disease (33-37). With the lack of an overt clinical profile in IgA-deficient humans, it has been difficult to discern the importance of IgA in the immune response to gastrointestinal viruses. Adding to this difficulty are the relatively few animal models of enteropathogenic or non-enteropathogenic gastrointestinal virus infections in which the pathogenesis and immune response, including IgA induction to the virus, faithfully models infection in humans. There are several reasons for the lack of robust animal models. Several of the common enteropathogenic and non-enteropathogenic viruses only replicate in humans or primates, limiting studies that can be performed to determine IgA importance (38). Other viruses infect non-primate animals but the pathogenesis is dramatically different from infection and disease in humans (38), leading to questions regarding the relevance of conclusions drawn from these models to human health.

Non-enteropathogenic viruses invade the body by either breeching or crossing the epithelium of the gastrointestinal tract (39-43). Although present in the gastrointestinal tract, in most cases these viruses do not infect a significant number of cells but once they have crossed the gastrointestinal tract barrier, disseminate systemically to access secondary target sites of viral replication (42). Because these viruses are able to spread systemically, IgG usually plays a significant role in protective immunity (44-50). However, there is evidence linking mucosal IgA to protective immunity for some of these viruses (Table 1).

Poliovirus, a good example of a non-enteropathogenic gastrointestinal virus, induces a secretory IgA response that appears to neutralize the virus and is associated with decreases in virus shedding in stool (51-55). Mucosal IgA correlates with protection against polio infection (56). An intestinal IgA response is also induced with the live replicating oral polio vaccine (OPV) and it is surmised that OPV prevents infection through IgA-mediated viral neutralization in the intestine. Live poliovirus vaccine appears to induce long-lived memory immune responses as elderly people who received this vaccine and still had detectable serum and salivary IgA were resistant to reinfection (56). In addition, IPV vaccination of individuals that were $20-44$ years of age and had previously been vaccinated with OPV induced $\operatorname{IgA}^{+} \alpha 4 \beta 7^{+}$antibody secreting cell by 7 days post vaccine but not in individuals of similar age previously vaccinated with IPV, which does not induce intestinal IgA responses. These data are consistent with the induction
Table 1 | Role of $\lg A$ in protective from non-enteropathogenic and pathogenic intestinal viral infections.

\begin{tabular}{llll}
\hline Virus & \multicolumn{2}{c}{$\operatorname{IgA}$} \\
\cline { 2 - 4 } & $\begin{array}{l}\text { Induced by } \\
\text { infection } \\
\text { (natural/exp) }\end{array}$ & $\begin{array}{l}\text { Correlate of } \\
\text { protection }\end{array}$ & $\begin{array}{l}\text { Required for } \\
\text { protection }\end{array}$ \\
\end{tabular}

\begin{tabular}{|c|c|c|c|c|}
\hline & & & & \\
\hline & & Humans & Animals & \\
\hline \multicolumn{5}{|c|}{ NON-ENTEROPATHOGENIC } \\
\hline Poliovirus & Y & Y & $?$ & ? \\
\hline Coxsackievirus & Y & $?$ & $?$ & ? \\
\hline Echovirus & Y & $?$ & $?$ & ? \\
\hline Hepatitis A & Y & $?$ & $?$ & $?$ \\
\hline Reovirus & Y & $?$ & Y & Y \\
\hline HIV & Y & $\mathrm{Y} / \mathrm{N}$ & $\mathrm{Y} / \mathrm{N}$ & ? \\
\hline \multicolumn{5}{|c|}{ ENTEROPATHOGENIC } \\
\hline Rotavirus & Y & Y & Y & Y \\
\hline Calicivirus & Y & $\mathrm{Y} / \mathrm{N}$ & $?$ & ? \\
\hline Adenovirus & Y & $?$ & $?$ & ? \\
\hline Astrovirus & Y & $?$ & $?$ & ? \\
\hline
\end{tabular}

$Y$, yes; N, no; ?, unknown.

of memory IgA responses in the intestine. Therefore, whether IgA memory in the intestine to enteric viral pathogens undergoes the continuous adaptation observed with a commensal organism (57) is still an open question. For other non-enteropathogenic viruses, such as hepatitis A, coxsackievirus, and echovirus, much less is known about the relative importance of mucosal IgA in protective immunity (Table 1).

Reovirus, although not causing significant disease, is often used as a model system of non-enteropathogenic infection in mice. In reovirus infection, following binding and transport across $\mathrm{M}$ cells in the Peyer's patches, the virus is distributed systemically where it can cause disease (58). It also infects the adjacent intestinal epithelium at the basolateral membrane (59) but is not an important cause of gastrointestinal disease in humans Reovirus infection induces intestinal IgA production and IgA protects against infection when administered orally at the same time as the virus or when secreted from subcutaneous tumors $(9,60)$. Mice lacking expression of IgA are susceptible to reinfection with reovirus (11) indicating that $\operatorname{IgA}$ is an essential component of immune protection. Whether the reovirus model faithfully predicts the role of IgA in immunity to other non-enteropathogenic viruses awaits definitive proof. Protective immunity against most nonenteropathogenic infections has focused on systemic immune responses or the immune response at the site of disease rather than on the mucosal IgA response. The lack of adequate animal models has severely limited insights into the relative importance of mucosal IgA in protective immunity to these viruses.

Enteropathogenic gastrointestinal viral infections are the major cause of diarrhea and vomiting disease in humans worldwide and most induce IgA within the first week after viral exposure. Astroviruses and adenovirus are important causes of acute gastroenteritis primarily in infants and young children as well as 
in the elderly and immunocompromised patients (61-68). There is limited evidence that protection from both adenovirus and astrovirus infections correlates with mucosal virus-specific IgA in humans $(34,69,70)$. These viruses lack small animal models, in which pathogenesis and immunity is similar to that observed in humans. The number of cases and disease severity of gastroenteritis caused by these two viruses is far less than that caused by calicivirus (71-74).

Two genera of caliciviruses, norovirus and sapovirus cause infectious gastroenteritis (75). Sapoviruses cause gastroenteritis in young children and in long term health care settings but the number of cases is far less than noroviruses (75). Norovirus is becoming the predominant cause of viral diarrhea in all age groups worldwide (76) and is the causative agent of $>96 \%$ of all outbreaks of non-bacterial gastroenteritis (77). Epidemiological data gathered from human studies suggests a link between mucosal IgA induced either by infection or by non-replicating vaccines and short term protective immunity from norovirus infection (7880). Elucidation of the role of the gastrointestinal IgA response to norovirus has been limited by the absence of animal models in which human noroviruses replicate or that mimic the course of gastrointestinal infection and disease in humans. Several nonhuman primate models have been developed with limited success in advancing knowledge of clinical infection and illness arising from norovirus infection (81-84). More has been gleaned from the gnotobiotic pig and calf models which exhibit diarrhea, virus shedding in feces, seroconversion, and immunocytopathic changes in the intestine (85-87). In norovirus infected gnotobiotic pigs, anti-norovirus IgA is detected as early as 6 days following virus exposure and diarrhea and severity moderately correlated with convalescent phase intestinal antibody IgA titers (87). Similarly, both norovirus-specific IgA and IgA secreting cells were present 28 days following norovirus exposure in gnotobiotic calves (86). Unlike norovirus infection in gnotobiotic piglet and calf, murine norovirus infection differs substantially from human norovirus pathogenesis, clinical manifestations, host receptors, and infected cell types (88) but a requirement for B cells and antibody in timely virus clearance and vaccine-induced protection is implicated in the mouse $(89,90)$. The limitations of these animal model systems, such as the lack of intestinal microbiota and differences in pathogenesis, have precluded elucidation of whether mucosal IgA is likley protective in human infection and disease.

Like norovirus, rotavirus is a major cause of gastroenteritis especially in pediatric populations where the disease is most severe. Rotavirus accounted for nearly half a million deaths in children younger than 5 years old worldwide each year prior to introduction of vaccines (91). However, unlike norovirus, mucosal rotavirus-specific IgA strongly correlates with less severe disease and prevention of rotavirus infection in humans (37, 92-95). The differences in pathogenesis between these two viruses and the lack of good reagents and model systems in which to advance our limited understanding of the pathogenesis and immune response to norovirus infection potentially explain these correlative differences. Rotavirus-specific IgA has been shown to neutralize the virus as well as mediate heterotypic protection (96). Vaccine development strategies primarily focused on utilizing live attenuated strains that replicate in the intestine and have been successful likely because of the induction of mucosal IgA responses. Unlike norovirus, there are excellent animal models of rotavirus infection and disease that range from horses to rodents that mimic human disease. From these models (discussed in more detail in the coming sections below), virus induced IgA has been shown to play an important role in clearance of infection and protection from reinfection.

\section{MECHANISMS OF IgA INDUCTION}

Protective IgA responses to gastrointestinal viruses are thought to be comprised of high affinity antibodies that recognize and neutralize the viruses. High affinity IgA producing cells arise from the actions of helper $\mathrm{T}$ cells, within the context of the germinal center environment in the gastrointestinal inductive sites, Peyer's patches, isolated lymphoid follicles, and mesenteric lymph nodes (97). These helper T cells signal B cells using such molecules as TGF $\beta$ and CD40, to induce class switch recombination and somatic hypermutation resulting in the production of high affinity $\operatorname{IgA}(98)$ that is thought to function to neutralize the intestinal virus. Once signaled to become a high affinity $\operatorname{IgA}^{+} \mathrm{B}$ cell, the cell leaves the inductive site germinal center and circulates back to the intestinal lamina propria based on cell surface expression of markers, such as $\alpha 4 \beta 7(97,99-101)$. This process takes at least $7-10$ days following initial virus infection in the gastrointestinal tract.

In contrast to the production of high affinity IgA that results from interactions between $\mathrm{T}$ and $\mathrm{B}$ cells in the germinal center environment, unmutated low affinity IgA can be synthesized very rapidly in the gastrointestinal tract in a $\mathrm{T}$ cell independent fashion $(102,103)$. This low affinity antibody primarily functions to limit penetration of commensal microbes through epithelial cells (104) and most believe that it does not play an important role in limiting pathogens, including gastrointestinal viruses. However, virus-specific intestinal IgA, that is presumably high affinity, develops rapidly and many acute viral infections are resolved prior to the time frame required for generation of germinal center high affinity IgA antibody. Mice that have defects in germinal center formation develop specific intestinal IgA responses, including to viruses (105-107), providing further evidence that germinal center reaction might not be necessary for clearance of infection and production of virus-specific antibody. Therefore, an alternate possibility is that IgA generated through T cell independent pathways develops sufficient affinity to limit viral replication. Rapid $\mathrm{T}$ cell-independent virus-specific antibody responses are generated during many acute virus infections, including VSV, influenza, and polio (108-116). These antibodies mediate virus clearance and limit replication and dissemination prior to generation of $\mathrm{T}$ cell-dependent IgA (117). Virus-specific IgA can be induced in the absence of CD4 ${ }^{+} \mathrm{T}$ cells $(110,118,119)$. Mice lacking expression of MHC II (120), CD40 (121), or CD40L (122) can exhibit antibody class-switching and it is thought that molecules such as BAFF and APRIL produced by dendritic and epithelial cells drive class switch recombination and somatic hypermutation in B cells independently of germinal centers (123-127). Emerging evidence implicates a greater role for $\mathrm{T}$ cell independent nongerminal center generated IgA in pathogen-specific responses in the intestine. 


\section{ROTAVIRUS: A MODEL SYSTEM TO STUDY INTESTINAL IgA INDUCTION}

Rotavirus is a highly infectious double-stranded RNA virus that replicates in epithelial cells of the small intestine (128-131). Virus is excreted in the stool and is transmitted from infected individuals by the fecal oral route. Infection, measured by excretion of the virus in stool, lasts on average 3-8 days and is manifested by fever, emesis, and diarrhea. Disease is most severe in the young, the elderly, and the immunocompromised. Rotavirus-specific intestinal IgA is one of the principle effectors of long term immunity based on correlative studies $(37,92-95)$. Rotavirus is one of the few gastrointestinal viral infections in which the pathogenesis and immune response in experimental animal models closely mimics that of humans. Virtually all naïve individuals and animals are susceptible to rotavirus infection but rotaviruses exhibit some species specificity. All of the animal models of rotavirus infection and disease (horse, cow, sheep, gnotobiotic piglet, rat, and mouse) exhibit the same primary tropism of virus to the small intestinal epithelial cells, excretion of the virus in the stool, kinetics of infection, most severe disease in the young, and induction of rotavirus-specific intestinal IgA that correlates with clearance of infection and protective immunity (129-149). Both humans and animals exhibit widespread systemic distribution of the virus $(141,150)$. The similarity of pathogenic features of disease and immunity between rotavirus infection in humans and across all animal models is nearly unique among gastrointestinal viral and bacterial infections making the rotavirus experimental animal models excellent systems for understanding human pathogenesis and immunity.

\section{ANIMAL MODELS}

The gnotobiotic piglet and the mouse model are the principle models of experimental rotavirus infection. Gnotobiotic piglets exhibit diarrheal disease after infection with multiple porcine and at least one human rotavirus strains and disease severity diminishes with age (136). Protection against human rotavirus infection correlates with both serum and intestinal rotavirus-specific IgA levels and antibody secreting cells in this model (136). Mice of all ages, irrespective of genetic background, are susceptible to murine rotavirus infection (e.g., $\mathrm{EC}_{\mathrm{wt}}$, EDIM, and $\mathrm{McN}$ ) but have limited susceptibility to non-murine strains of rotavirus (132, 151-153). Rotavirus-associated diarrheal disease in mice is age restricted and is observed only up to 2 weeks of age (151). Following inoculation of adult mice with murine strains, rotavirus is detectable in stool by 24-48 h and systemically in the blood between 48 and $72 \mathrm{~h}$ (154). Mice resolve infection between 5 and 7 days after viral inoculation concurrent with the detection of stool IgA (151). Rotavirusspecific IgA is the predominant immunoglobulin response in the intestine and IgA titers persist long term. Mice are completely protected from reinfection for the lifetime of the mouse (155).

\section{PASSIVE PROTECTION}

Passive protection from rotavirus has been demonstrated in many animal model systems and early studies indicated that it is primarily mediated by presence of antibody in the intestine not in the circulation (156-158). In mice, IgA was shown to be more potent than IgG in protecting pups from rotavirus disease but protection was observed with both isotypes (156). Passive protection is mediated by neutralizing antibody to two rotavirus neutralization antigens VP4 and VP7 (159) but an IgA monoclonal antibody to VP6 administered by backpack also protects through intracellular neutralization (160-162). Passive protection of infants and toddlers from nosocomial infection or during an outbreak in an orphanage has been assessed in several small studies in which children were administered either human gammaglobulin or bovine colostrum from hyperimmunized cows (163-166). Significant protection was observed in some but not all studies. Whether protection was mediated by rotavirus-specific IgA or IgG is not known. A role for IgA in passive protection of children from rotavirus has been suggested based on breast feeding studies but not all studies have supported the protective effects of breast feeding against rotavirus (167-171).

\section{PROTECTION INDUCED BY VACCINES}

During the development of both non-replicating and replicating rotavirus vaccine candidates, IgA has been explored as major correlate of protective immunity induced by rotavirus vaccines (139, 153, 172-185). However, demonstration of a conclusive role for vaccine-induced IgA in protective immunity against infection and disease in children has remained elusive $(186,187)$. In the last 7 years, Rotarix (GSK Biologicals) and RotaTeq (Merck), two live oral rotavirus vaccines were licensed for use and have been show to prevent severe disease and death in children (188-192). Lower levels of vaccine-induced serum IgA titers correlate with higher child mortality (193). In addition, vaccine efficacy and duration of protection could be predicted by serum IgA titers. What is lacking in these analyses is whether the levels of serum IgA induced by the rotavirus vaccines can accurately predict protection from infection. One caveat to determining the role of vaccine-induced IgA in protective immunity may be that in humans, there are differences between serum IgA and IgA present in the intestine, the most significant being that serum IgA is a different isoform than the IgA present at mucosal surfaces. Further studies are necessary to identify whether vaccine-induced serum or mucosal IgA are true effectors of rotavirus protective immunity.

\section{IgA AND ROTAVIRUS}

The conclusion that gastrointestinal IgA is critical for resolution of rotavirus infection and in protection from reinfection is drawn mainly from studies in gene knockout mice. Mice lacking B cells exhibit significant delays in clearance of a rotavirus infection (194) and fail to establish protective immunity against a second infection (140). These deficits contrast to the limited to no defects in clearance or protection in mice lacking $\mathrm{T}$ cells $(118,195)$. High levels of protection against rotavirus infection are induced in mice lacking T cells, T cell knockout animals produce $\sim 60 \%$ of wild type rotavirus-specific IgA (118). T cell independent antibody plays a role in resolution of infection (196). Mice without IgA exhibit similar delays in viral clearance and in the development of protective immunity (197), leading to the conclusion that IgA is critical. Further conclusions about the importance of mucosal IgA to rotavirus immunity come from studies in mice lacking the ability to transport IgA and IgM from the intestinal lamina propria to the lumen due to the absence of J-chain expression, a protein required for transport. J-chain knockout mice exhibit an almost identical delay 
in clearance and absence of protective immunity to that reported in both B cell and IgA knockout mice (179). Together these studies indicate that IgA in the intestinal lumen is a key component in the immune response to rotavirus.

Emerging work has focused on the type and origin of B cells that are required for the IgA response to rotavirus. Adoptive transfer studies where $\alpha 4 \beta 7^{-}$and $\alpha 4 \beta 7^{+}$B cells were transferred into mice chronically infected with rotavirus demonstrate that $\alpha 4 \beta 7$ expression, which is expressed on B cells that circulate to the intestinal lamina propria, plays an important role in clearance of an ongoing rotavirus infection (198). In addition to $\alpha 4 \beta 7$, recruitment of $B$ cells to the intestine also depends on expression of CCR9 and CCR10, receptors for ligands CCL25 and CCL28 which are exclusively expressed in the gastrointestinal tract (199). Circulating B cells that ultimately reach the intestine can originate from several sources including the peritoneal cavity (B1 cells), the Peyer's patches (naïve B cells), and the bone marrow (memory B cells). Data in the gnotobiotic piglet model suggests that bone marrow B cells do not play a significant role in rotavirus immunity (200). Although B1 cells are a major source of intestinal antibody, B1 cells are not critical to the IgA response to rotavirus (201). B cells in the Peyer's patches are currently being studied and hold great potential for understanding fundamentals of induction of the IgA response to rotavirus. Peyer's patches are inductive sites for mucosal IgA responses in the small intestine (202). Rotavirus induces specific IgA antibody in the PP and this precedes appearance of IgA in the lamina propria (101), suggestive that rotavirus-specific antibodies originate in the PP and not the lamina propria. This is supported by studies in mice that lack expression of the TNF family member LT $\alpha$ that do not develop Peyer's patches (203) and these mice are unable to clear rotavirus infection or produce stool rotavirus-specific IgA following virus exposure (204). This is similar to the response seen in B cell, IgA, and J-chain knockout animals $(140,179,194,197)$. Therefore, Peyer's patch B cells appear to be critical for intestinal rotavirus-specific IgA. Analysis of the Peyer's patches of mice within 24-48 h after infection indicates there are large increases in activated B cells (205), which may be driven by type I interferons secreted by dendritic cells (206). This activation is followed by an increase in local production of rotavirus-specific antibody (205). Similar levels of Peyer's patch $B$ cell activation and early antibody production occur in the absence of T cells (205), indicating that the early Peyer's patch B cell response to rotavirus is $\mathrm{T}$ cell-independent with minimal $\mathrm{T}$ cell activation and inflammatory response induced during infection $(205,207)$. Since T cells are a mainstay of the germinal center environment, $\mathrm{T}$ cell independence suggests the lack of germinal center involvement in the rotavirus induced $\mathrm{B}$ cell activation and IgA induction. Mice lacking the classical germinal center molecules CD40 and CD40L produce wild type levels of intestinal rotavirus-specific IgA (107). Indeed, the first rotavirus-specific B cells detected in the Peyer's patch early after infection are extrafollicular B cells (101). Therefore, rotavirus activates Peyer's patch $\mathrm{B}$ cells and induces IgA through non-classical T cell independent extra-follicular pathways (Figure 1).

Although experimental models of rotavirus infection have been used to characterize the $\mathrm{B}$ cell and IgA response to rotavirus, there is still more to learn from these models about the role of IgA in gastrointestinal virus infections. Little is known about signals that direct PP B cells toward extra-follicular growth instead of germinal center formation during rotavirus infection in the mouse. Classically, TGF $\beta$ and signaling through CD40 modulate the switch to IgA in the germinal center with the help of cytokines such as IL-10, L-6, IL-4, and IL-2 produced by T cells (103). Consistent with the hypothesis that germinal centers are not playing a large role, IL-6 is not required for rotavirus-specific IgA production or virus immunity (208). It remains to be discerned whether any of the other cytokines linked to IgA induction are critical to or affect mucosal IgA levels to rotavirus. The evidence that rotavirus induces extrafollicular B cells that do not rely on T cell help raises the possibility that other factors are necessary to direct the $\mathrm{B}$ cell response. BAFF and APRIL are candidates as well as yet unidentified factors (125, 209). Rotavirus infection in mice lacking BAFF and APRIL expression should determine whether these molecules are critical for the intestinal IgA response to rotavirus. Interestingly, absence of CCR6 results in a 70-80\% decrease in rotavirus-specific IgA levels compared to wild type mice (210). CCR6 is critical for localization of dendritic cells to the subepithelial dome of the Peyer's patch (210) raising the question as whether Peyer's patch dendritic cells regulate induction of B cell activation and IgA responses during rotavirus infection. Rotavirus infection activates dendritic cells in the Peyer's patches prior to and concurrent with the activation of the B cells (211) and activation of B cells is dependent on dendritic cells (206). The Peyer's patch activated dendritic cells produced IL$10, \mathrm{IL}-12 / 23$, and TNF $\alpha$ and upregulate expression of INF $\alpha$ and INF $\beta$ but B cell activation appears to be dependent on type I IFN $(206,211)$. The dendritic cell derived signaling contributed to the IgA response to rotavirus (206).

\section{USE OF THE ROTAVIRUS ANIMAL MODELS TO OPEN NEW AREAS OF RESEARCH INTO VIRAL-SPECIFIC IgA}

Because rotavirus induces a profound intestinal IgA response, the rotavirus model systems are valuable tools in which the plasticity of the IgA repertoire can be explored. Almost nothing is known about how the diversity and specificity of IgA in the gastrointestinal tract is shaped or altered during viral infections. There has been some indication, using methods that involve expansion of single rotavirus-specific circulating B cells, that there is low number of somatic hypermutation in circulating rotavirusspecific $\mathrm{IgA}^{+} \mathrm{B}$ cells isolated from infants and adults that have previously experienced a rotavirus infection and that $\mathrm{VH} 1-46$ is the immunodominant gene segment, except in $\mathrm{CD}^{+} \mathrm{B}$ cells in young children (212-214). The availability of more rapid and broad sequencing approaches provides a new methodology to probe and understand the diversity and composition of the intestinal IgA repertoire. Using high throughput sequencing, the IgA producing plasma cell pool in the small intestine was recently demonstrated to contain two subfractions: frequent oligoclonal plasma cells that have low diversity and are present in high numbers and polyclonal plasma cells that have high diversity but are present in low amounts (215). Analysis of over one million Vh sequences extracted from plasma cells in the proximal, middle, and distal portions of the small intestine revealed that there are both highly expanded IgA secreting plasma cells (clonally related) as well as low frequency clones (clonally unrelated). The authors 


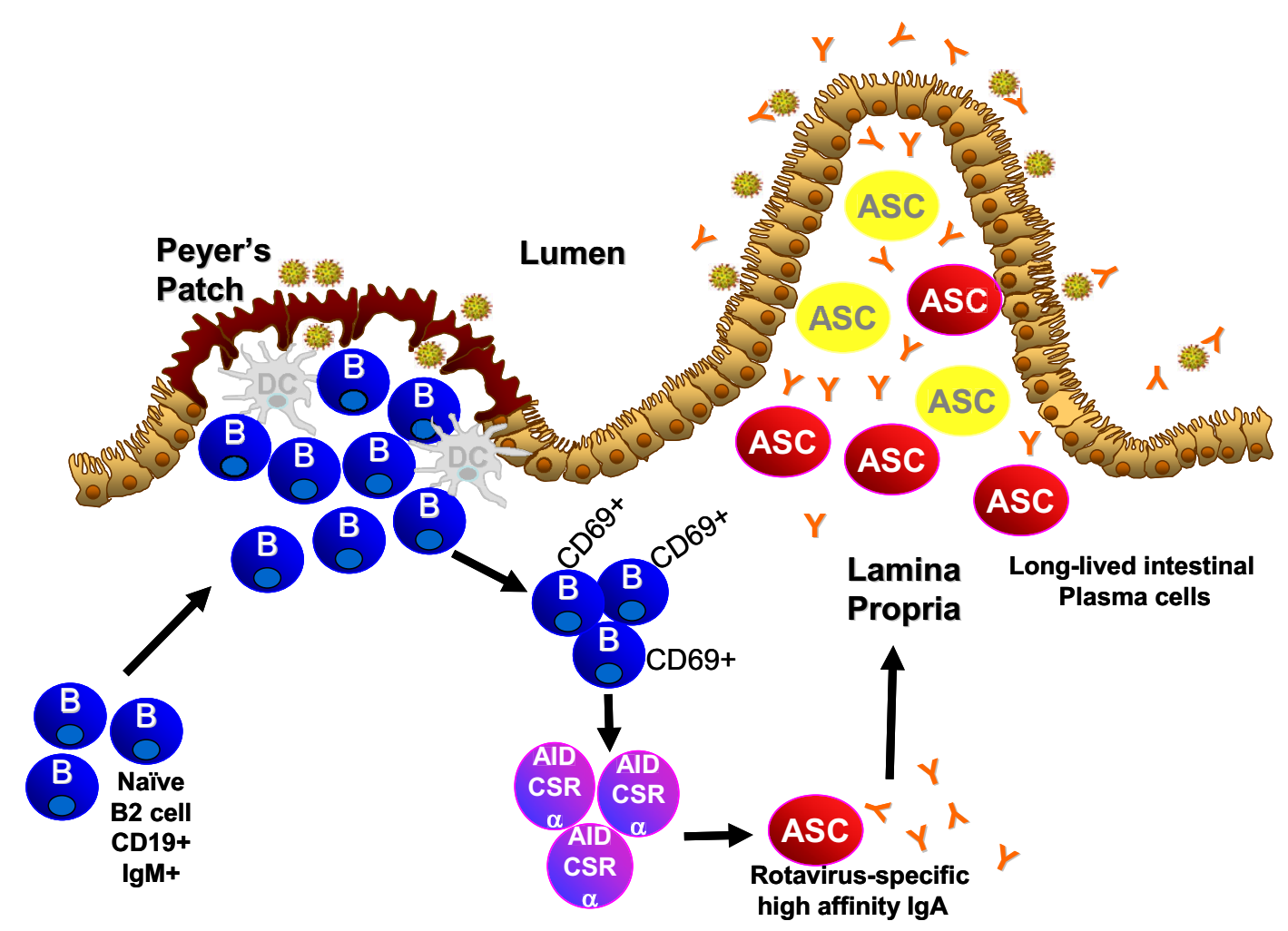

FIGURE 1 | Novel pathway of IgA induction and longevity in the intestine

concluded that there is more diversity in the IgA repertoire than has previously been demonstrated. It remains to be determined how a highly pathogenic viral infection that induces a substantial IgA response alters the plasma cell composition. In both animals and humans, rotavirus-specific IgA, once induced, can persist for long periods of time $(136,155,216-220)$. This persistence suggests that rotavirus infection makes a permanent alteration to the IgA repertoire. Next-generation sequencing is a powerful new tool which has the potential to reveal pivotal insights as to how viral pathogens shape the IgA composition within the gastrointestinal tract.

The persistence of rotavirus-specific IgA in humans and experimental animal models is intriguing and provides the perfect backdrop in which to study the maintenance of viral-specific IgA antibody secreting cells. Plasma cells develop following reactivation of quiescent memory B cells. Antibody secreting cells were thought to be short lived ( 2-3 weeks) (221) but this is still being debated. Recently, populations of long-lived plasma cells that produce antibodies for several to many years have been shown to reside in "niches" in the spleen, lymph nodes, and bone marrow (222). The repertoire of these plasma cell niches could be rapidly recalled after temporary depletion indicating the likelihood that these plasma cell niches have a memory component (215). Several characteristics of rotavirus infection in mice indicate that longlived IgA $\mathrm{A}^{+}$plasma cells are generated following rotavirus infection and mediate protective immunity. First, infection of naïve mice results in intestinal and fecal rotavirus-specific IgA that stabilizes around 3 weeks after infection and stays constant over the lifetime of the mouse $(132,151)$. Second, murine rotavirus infection in mice induces lifetime protection against reinfection $(132,151)$. Upon re-exposure to rotavirus, viral proteins are not detected in the intestinal tract or in the feces $(132,151)$ and there is no increase in the titers of rotavirus-specific IgA in the feces (132, 151). The lack of discernible induction of antibody titers following re-exposure suggest: (i) that there is no reactivation of rotavirus-specific memory B cells or generation of new antibody secreting cells and (ii) that the antibody produced by the longlived plasma cells is sufficient to neutralize the viral challenge. In addition, there is no indication that rotavirus replicates or that antigens are maintained chronically in the mouse past the time when it is detectable in stool $(220,223)$. This suggests that the plasma cells that produce rotavirus-specific antibody do so in the absence of virus. Work in the gnotobiotic piglet indicates that the bone marrow does not house the IgA response to rotavirus but rather the plasma cells are located in the intestinal lamina propria (200). It remains to be determined whether the specific environment of the intestinal lamina propria facilitates the development and maintenance of long-lived IgA secreting plasma cells that have a memory component (Figure 1).

\section{SUMMARY}

Although IgA is produced in large quantities in the gastrointestinal tract, its importance in the immune response to gastrointestinal viral infections is unclear. In part, this is due to the lack of good 
animal models in which the pathogenesis, disease, and immune response induced during gastrointestinal viral infection reflects that which occurs in humans. The animal models of rotavirus infection closely mimic many parameters of infection in humans including a profound induction of rotavirus-specific intestinal IgA that correlates with clearance of infection and protection from reinfection. These animal models a currently being used to investigate and characterize the molecular pathways through which the virus induces the intestinal IgA response and will contribute significantly to our understanding of the important role IgA plays in the defense against intestinal virus infections. The models, combined with new technologies, are positioned to reveal new and exciting information as to the location, diversity, and maintenance of long-lived $\operatorname{IgA}^{+}$plasma secreting cells. Furthermore, these studies will facilitate the design and development of future oral vaccines by providing new and more efficient targets to induce protective IgA.

\section{REFERENCES}

1. World Health Organization. The World Health Report: Making a Difference. Geneva: World Health Organization (2000). Report.

2. Everhart JE, Ruhl CE. Burden of digestive diseases in the United States part I: overall and upper gastrointestinal diseases. Gastroenterology (2009) 136:376-86. doi:10.1053/j.gastro.2009.01.015

3. Peery AF, Dellon ES, Lund J, Crockett SD, McGowan CE, Bulsiewicz WJ, et al. Burden of gastrointestinal disease in the United States: 2012 update. Gastroenterology (2012) 143:1179-87. doi:10.1053/j.gastro.2012.08.002

4. Golby SJ, Spencer J. Where do IgA plasma cells in the gut come from? Gut (2002) 51:150-1. doi:10.1136/gut.51.2.150

5. Chodirker WB, Tomasi TB Jr. Gamma-globulins: quantitative relationships in human serum and nonvascular fluids. Science (1963) 142:1080-1. doi:10.1126/ science. 142.3595 .1080

6. Tomasi TB. The discovery of secretory IgA and the mucosal immune system. Immunol Today (1992) 13:416-8. doi:10.1016/0167-5699(92)90093-M

7. Apter FM, Michetti P, Winner LS III, Mack JA, Mekalanos JJ, Neutra MR. Analysis of the roles of antilipopolysaccharide and anti-cholera toxin immunoglobulin A (IgA) antibodies in protection against Vibrio cholerae and cholera toxin by use of monoclonal IgA antibodies in vivo. Infect Immun (1993) 61: 5279-85.

8. Apter FM, Lencer WI, Finkelstein RA, Mekalanos JJ, Neutra MR. Monoclonal immunoglobulin A antibodies directed against cholera toxin prevent the toxininduced chloride secretory response and block toxin binding to intestinal epithelial cells in vitro. Infect Immun (1993) 61:5271-8.

9. Hutchings AB, Helander A, Silvey KJ, Chandran K, Lucas WT, Nibert ML, et al. Secretory immunoglobulin A antibodies against the sigmal outer capsid protein of reovirus type 1 Lang prevent infection of mouse Peyer's patches. J Virol (2004) 78:947-57. doi:10.1128/JVI.78.2.947-957.2004

10. Mantis NJ, McGuinness CR, Sonuyi O, Edwards G, Farrant SA. Immunoglobulin A antibodies against ricin A and B subunits protect epithelial cells from ricin intoxication. Infect Immun (2006) 74:3455-62. doi:10.1128/ IAI.02088-05

11. Silvey KJ, Hutchings AB, Vajdy M, Petzke MM, Neutra MR. Role of immunoglobulin A in protection against reovirus entry into murine Peyer's patches. J Virol (2001) 75:10870-9. doi:10.1128/JVI.75.22.10870-10879.2001

12. Suzuki K, Meek B, Doi Y, Muramatsu M, Chiba T, Honjo T, et al. Aberrant expansion of segmented filamentous bacteria in IgA-deficient gut. Proc Natl Acad Sci U S A (2004) 101:1981-6. doi:10.1073/pnas.0307317101

13. Fagarasan S, Muramatsu M, Suzuki K, Nagaoka H, Hiai H, Honjo T. Critical roles of activation-induced cytidine deaminase in the homeostasis of gut flora. Science (2002) 298:1424-7. doi:10.1126/science.1077336

14. Peterson DA, McNulty NP, Guruge JL, Gordon JI. IgA response to symbiotic bacteria as a mediator of gut homeostasis. Cell Host Microbe (2007) 2:328-39. doi:10.1016/j.chom.2007.09.013

15. Fernandez MI, Pedron T, Tournebize R, Olivo-Marin JC, Sansonetti PJ, Phalipon A. Anti-inflammatory role for intracellular dimeric immunoglobulin a by neutralization of lipopolysaccharide in epithelial cells. Immunity (2003) 18:739-49. doi:10.1016/S1074-7613(03)00122-5

16. Oen K, Petty RE, Schroeder ML. Immunoglobulin A deficiency: genetic studies. Tissue Antigens (1982) 19:174-82. doi:10.1111/j.1399-0039.1982.tb01437.x

17. Holt PD, Tandy NP, Anstee DJ. Screening of blood donors for IgA deficiency: a study of the donor population of south-west England. J Clin Pathol (1977) 30:1007-10. doi:10.1136/jcp.30.11.1007

18. Wells JV, McNally MP, King MA. Selective IgA deficiency in Australian blood donors. Aust N Z J Med (1980) 10:410-3. doi:10.1111/j.1445-5994.1980. tb04091.x

19. Clark JA, Callicoat PA, Brenner NA, Bradley CA, Smith DM Jr. Selective IgA deficiency in blood donors. Am J Clin Pathol (1983) 80:210-3.

20. Conley ME, Arbeter A, Douglas SD. Serum levels of IgA1 and IgA2 in children and in patients with IgA deficiency. Mol Immunol (1983) 20:977-81. doi:10.1016/0161-5890(83)90038-X

21. Zinneman HH, Kaplan AP. The association of giardiasis with reduced intestinal secretory immunoglobulin A. Am J Dig Dis (1972) 17:793-7. doi:10.1007/ BF02231148

22. Cunningham-Rundles C, Brandeis WE, Pudifin DJ, Day NK, Good RA. Autoimmunity in selective IgA deficiency: relationship to anti-bovine protein antibodies, circulating immune complexes and clinical disease. Clin Exp Immunol (1981) 45:299-304.

23. Meini A, Pillan NM, Villanacci V, Monafo V, Ugazio AG, Plebani A. Prevalence and diagnosis of celiac disease in IgA-deficient children. Ann Allergy Asthma Immunol (1996) 77:333-6. doi:10.1016/S1081-1206(10)63329-7

24. Aghamohammadi A, Cheraghi T, Gharagozlou M, Movahedi M, Rezaei N, Yeganeh M, et al. IgA deficiency: correlation between clinical and immunological phenotypes. J Clin Immunol (2009) 29:130-6. doi:10.1007/s10875-0089229-9

25. Yel L. Selective IgA deficiency. J Clin Immunol (2010) 30:10-6. doi:10.1007/ s10875-009-9357-x

26. Cunningham-Rundles C. Physiology of IgA and IgA deficiency. J Clin Immunol (2001) 21:303-9. doi:10.1023/A:1012241117984

27. Hammarstrom L, Vorechovsky I, Webster D. Selective IgA deficiency (SIgAD) and common variable immunodeficiency (CVID). Clin Exp Immunol (2000) 120:225-31. doi:10.1046/j.1365-2249.2000.01131.x

28. Ammann AJ, Hong R. Selective IgA deficiency: presentation of 30 cases and a review of the literature. Medicine (Baltimore) (1971) 50:223-36. doi:10.1097/ 00005792-197105000-00004

29. Ammann AJ, Hong R. Selective IgA deficiency and autoimmunity. NEngl J Med (1971) 284:985-6. doi:10.1056/NEJM197104292841727

30. Klemola T, Seppala I, Savilahti E. Serum IgG subclass levels in paediatric clinic patients with variable degrees of IgA deficiency. J Clin Lab Immunol (1988) 25:29-34.

31. Natvig IB, Johansen FE, Nordeng TW, Haraldsen G, Brandtzaeg P. Mechanism for enhanced external transfer of dimeric IgA over pentameric IgM: studies of diffusion, binding to the human polymeric Ig receptor, and epithelial transcytosis. J Immunol (1997) 159:4330-40.

32. Barros MD, Porto MH, Leser PG, Grumach AS, Carneiro-Sampaio MM. Study of colostrum of a patient with selective IgA deficiency. Allergol Immunopathol (Madr) (1985) 13:331-4.

33. Scott RM, Dudding BA, Romano SV, Russell PK. Enteric immunization with live adenovirus type 21 vaccine. II. Systemic and local immune responses following immunization. Infect Immun (1972) 5:300-4.

34. Nishio O, Sakae K, Ishihara Y, Isomura S, Inouye S. Adenovirus infection and specific secretory IgA responses in the intestine of infants. Microbiol Immunol (1992) 36:623-31.

35. Riepenhoff-Talty M, Bogger-Goren S, Li P, Carmody PJ, Barrett HJ, Ogra PL. Development of serum and intestinal antibody response to rotavirus after naturally acquired rotavirus infection in man. J Med Virol (1981) 8:215-22.

36. Ceyhan M, Kanra G, Secmeer G, Midthun K, Davidson BL, Zito ET, et al. Take of rhesus-human reassortant tetravalent rotavirus vaccine in breast-fed infants. Acta Paediatr (1993) 82:223-7. doi:10.1111/j.1651-2227.1993.tb12646.x

37. Hjelt K, Grauballe PC, Paerregaard A, Nielsen OH, Krasilnikoff PA. Protective effect of preexisting rotavirus-specific immunoglobulin A against naturally acquired rotavirus infection in children. J Med Virol (1987) 21:39-47. doi:10.1002/jmv.1890210106

38. Zak O, Sande M. Handbook of Animal Models of Infection. San Diego, CA: Academic Press (1999). 
39. Asher LV, Binn LN, Mensing TL, Marchwicki RH, Vassell RA, Young GD. Pathogenesis of hepatitis A in orally inoculated owl monkeys (Aotus trivirgatus). J Med Virol (1995) 47:260-8. doi:10.1002/jmv.1890470312

40. Karayiannis P, Jowett T, Enticott M, Moore D, Pignatelli M, Brenes F, et al. Hepatitis A virus replication in tamarins and host immune response in relation to pathogenesis of liver cell damage. J Med Virol (1986) 18:261-76. doi:10.1002/jmv.1890180308

41. Astaldi G, Grandini U, Poggi C, Strosselli E. Intestinal biopsy in acute hepatitis. Am J Dig Dis (1964) 9:237-45. doi:10.1007/BF02232127

42. Sabin AB. The significance of viruses recovered from the intestinal tracts of healthy infants and children. Ann N Y Acad Sci (1956) 66:226-30. doi:10.1111/ j.1749-6632.1956.tb40126.x

43. Bodian D. Emerging concept of poliomyelitis infection. Science (1955) 122:105-8. doi:10.1126/science.122.3159.105

44. Nathanson N, Bodian D. Experimental poliomyelitis following intramuscular virus injection. II. Viremia and the effect of antibody. Bull Johns Hopkins Hosp (1961) 108:320-33.

45. Slusarczyk J, Hansson BG, Nordenfelt E, Krawczynski K, Karwowska S, Knap J. Etiopathogenetic aspects of hepatitis A II. Specific and nonspecific humoral immune response during the course of infection. J Med Virol (1984) 14:269-76. doi:10.1002/jmv.1890140311

46. Stapleton JT. Host immune response to hepatitis A virus. J Infect Dis (1995) 171(Suppl 1):S9-14. doi:10.1093/infdis/171.Supplement_1.S9

47. Stapleton JT, Lange DK, LeDuc JW, Binn LN, Jansen RW, Lemon SM. The role of secretory immunity in hepatitis A virus infection. J Infect Dis (1991) 163:7-11. doi:10.1093/infdis/163.1.7

48. Tilzey AJ, Palmer SJ, Barrow S, Perry KR, Tyrrell H, Safary A, et al. Clinical trial with inactivated hepatitis $\mathrm{A}$ vaccine and recommendations for its use. $B M J$ (1992) 304:1272-6. doi:10.1136/bmj.304.6837.1272

49. Rager-Zisman B, Allison AC. Effects of immunosuppression on coxsackie B-3 virus infection in mice, and passive protection by circulating antibody. J Gen Virol (1973) 19:339-51. doi:10.1099/0022-1317-19-3-329

50. Rager-Zisman B, Allison AC. The role of antibody and host cells in the resistance of mice against infection by coxsackie B-3 virus. J Gen Virol (1973) 19:329-38. doi:10.1099/0022-1317-19-3-329

51. Ogra PL, Karzon DT, Righthand F, MacGillivray M. Immunoglobulin response in serum and secretions after immunization with live and inactivated poliovaccine and natural infection. N Engl J Med (1968) 279:893-900. doi:10.1056/ NEJM196810242791701

52. Ogra PL, Karzon DT. Distribution of poliovirus antibody in serum, nasopharynx and alimentary tract following segmental immunization of lower alimentary tract with poliovaccine. J Immunol (1969) 102:1423-30.

53. Onorato IM, Modlin JF, McBean AM, Thoms ML, Losonsky GA, Bernier RH. Mucosal immunity induced by enhance-potency inactivated and oral polio vaccines. J Infect Dis (1991) 163:1-6. doi:10.1093/infdis/163.1.1

54. Keller R, Dwyer JE. Neutralization of poliovirus by IgA coproantibodies. J Immunol (1968) 101:192-202.

55. Keller R, Dwyer JE, Oh W, D'Amodio M. Intestinal IgA neutralizing antibodies in newborn infants following poliovirus immunization. Pediatrics (1969) 43:330-8.

56. Buisman AM, Abbink F, Schepp RM, Sonsma JA, Herremans T, Kimman TG. Preexisting poliovirus-specific IgA in the circulation correlates with protection against virus excretion in the elderly. J Infect Dis (2008) 197:698-706. doi:10.1086/527487

57. Hapfelmeier S, Lawson MA, Slack E, Kirundi JK, Stoel M, Heikenwalder M, et al. Reversible microbial colonization of germ-free mice reveals the dynamics of IgA immune responses. Science (2010) 328:1705-9. doi:10.1126/science. 1188454

58. Wolf JL, Rubin DH, Finberg R, Kauffman RS, Sharpe AH, Trier JS, et al. Intestinal M cells: a pathway for entry of reovirus into the host. Science (1981) 212:471-2. doi:10.1126/science.6259737

59. Bass DM, Trier JS, Dambrauskas R, Wolf JL. Reovirus type I infection of small intestinal epithelium in suckling mice and its effect on $\mathrm{M}$ cells. Lab Invest (1988) 58:226-35.

60. Haneberg B, Kendall D, Amerongen HM, Apter FM, Kraehenbuhl JP, Neutra MR. Induction of specific immunoglobulin A in the small intestine, colonrectum, and vagina measured by a new method for collection of secretions from local mucosal surfaces. Infect Immun (1994) 62:15-23.
61. Lewis DC, Lightfoot NF, Cubitt WD, Wilson SA. Outbreaks of astrovirus type 1 and rotavirus gastroenteritis in a geriatric in-patient population. J Hosp Infect (1989) 14:9-14. doi:10.1016/0195-6701(89)90128-X

62. Chiba S, Nakata S, Nakamura I, Taniguchi K, Urasawa S, Fujinaga K, et al. Outbreak of infantile gastroenteritis due to type 40 adenovirus. Lancet (1983) 2:954-7. doi:10.1016/S0140-6736(83)90463-4

63. Appleton H, Buckley M, Robertson MH, Thom BT. A search for faecal viruses in new-born and other infants. J Hyg (Lond) (1978) 81:279-83. doi:10.1017/S0022172400025110

64. Yolken RH, Lawrence F, Leister F, Takiff HE, Strauss SE. Gastroenteritis associated with enteric type adenovirus in hospitalized infants. J Pediatr (1982) 101:21-6. doi:10.1016/S0022-3476(82)80173-X

65. Uhnoo I, Wadell G, Svensson L, Johansson ME. Importance of enteric adenoviruses 40 and 41 in acute gastroenteritis in infants and young children. J Clin Microbiol (1984) 20:365-72.

66. Yolken RH, Bishop CA, Townsend TR, Bolyard EA, Bartlett J, Santos GW, et al. Infectious gastroenteritis in bone-marrow-transplant recipients. $N$ Engl J Med (1982) 306:1010-2. doi:10.1056/NEJM198204293061701

67. Troussard X, Bauduer F, Gallet E, Freymuth F, Boutard P, Ballet JJ, et al. Virus recovery from stools of patients undergoing bone marrow transplantation. Bone Marrow Transplant (1993) 12:573-6.

68. Chikhi-Brachet R, Bon F, Toubiana L, Pothier P, Nicolas JC, Flahault A, et al. Virus diversity in a winter epidemic of acute diarrhea in France. J Clin Microbiol (2002) 40:4266-72. doi:10.1128/JCM.40.11.4266-4272.2002

69. Kurtz J, Lee T. Astrovirus gastroenteritis age distribution of antibody. Med Microbiol Immunol (1978) 166:227-30. doi:10.1007/BF02121154

70. Unicomb LE, Jarecki-Khan K, Hall A, Podder G. Previous enteric adenovirus infection does not protect against subsequent symptomatic infection: longitudinal follow-up of eight infants. Microbiol Immunol (1996) 40:161-8.

71. Glass RI, Parashar UD, Estes MK. Norovirus gastroenteritis. N Engl J Med (2009) 361:1776-85. doi:10.1056/NEJMra0804575

72. Dennehy PH. Viral gastroenteritis in children. Pediatr Infect Dis J (2011) 30:63-4. doi:10.1097/INF.0b013e3182059102

73. Tran A, Talmud D, Lejeune B, Jovenin N, Renois F, Payan C, et al. Prevalence of rotavirus, adenovirus, norovirus, and astrovirus infections and coinfections among hospitalized children in northern France. J Clin Microbiol (2010) 48:1943-6. doi:10.1128/JCM.02181-09

74. Chhabra P, Payne DC, Szilagyi PG, Edwards KM, Staat MA, Shirley SH, et al. Etiology of viral gastroenteritis in children $<5$ years of age in the United States, 2008-2009. J Infect Dis (2013) 208:790-800. doi:10.1093/infdis/jit254

75. Glass RI, Noel J, Ando T, Fankhauser R, Belliot G, Mounts A, et al. The epidemiology of enteric caliciviruses from humans: a reassessment using new diagnostics. J Infect Dis (2000) 181(Suppl 2):S254-61. doi:10.1086/315588

76. Patel MM, Widdowson MA, Glass RI, Akazawa K, Vinje J, Parashar UD. Systematic literature review of role of noroviruses in sporadic gastroenteritis. Emerg Infect Dis (2008) 14:1224-31. doi:10.3201/eid1408.071114

77. Patel MM, Hall AJ, Vinje J, Parashar UD. Noroviruses: a comprehensive review. J Clin Virol (2009) 44:1-8. doi:10.1016/j.jcv.2008.10.009

78. Okhuysen PC, Jiang X, Ye L, Johnson PC, Estes MK. Viral shedding and fecal IgA response after Norwalk virus infection. J Infect Dis (1995) 171:566-9. doi:10.1093/infdis/171.3.566

79. Iritani N, Seto T, Hattori H, Natori K, Takeda N, Kubo H, et al. Humoral immune responses against norovirus infections of children. J Med Virol (2007) 79:1187-93. doi:10.1002/jmv.20897

80. Tacket CO, Sztein MB, Losonsky GA, Wasserman SS, Estes MK. Humoral, mucosal, and cellular immune responses to oral Norwalk virus-like particles in volunteers. Clin Immunol (2003) 108:241-7. doi:10.1016/S1521-6616(03) 00120-7

81. Wyatt RG, Greenberg HB, Dalgard DW, Allen WP, Sly DL, Thornhill TS, et al. Experimental infection of chimpanzees with the Norwalk agent of epidemic viral gastroenteritis. J Med Virol (1978) 2:89-96. doi:10.1002/jmv.1890020203

82. Subekti DS, Tjaniadi P, Lesmana M, McArdle J, Iskandriati D, Budiarsa IN, et al. Experimental infection of Macaca nemestrina with a Toronto Norwalklike virus of epidemic viral gastroenteritis. J Med Virol (2002) 66:400-6. doi:10.1002/jmv.2159

83. Rockx BH, Bogers WM, Heeney JL, van Amerongen G, Koopmans MP. Experimental norovirus infections in non-human primates. J Med Virol (2005) 75:313-20. doi:10.1002/jmv.20273 
84. Jiang B, McClure HM, Fankhauser RL, Monroe SS, Glass RI. Prevalence of rotavirus and norovirus antibodies in non-human primates. J Med Primatol (2004) 33:30-3. doi:10.1111/j.1600-0684.2003.00051.x

85. Cheetham S, Souza M, Meulia T, Grimes S, Han MG, Saif LJ. Pathogenesis of a genogroup II human norovirus in gnotobiotic pigs. J Virol (2006) 80:10372-81. doi:10.1128/JVI.00809-06

86. Souza M, Azevedo MS, Jung K, Cheetham S, Saif LJ. Pathogenesis and immune responses in gnotobiotic calves after infection with the genogroup II.4-HS66 strain of human norovirus. J Virol (2008) 82:1777-86. doi:10.1128/JVI.0134707

87. Souza M, Cheetham SM, Azevedo MS, Costantini V, Saif LJ. Cytokine and antibody responses in gnotobiotic pigs after infection with human norovirus genogroup II.4 (HS66 strain). J Virol (2007) 81:9183-92. doi:10.1128/JVI. 00558-07

88. Karst SM, Wobus CE, Lay M, Davidson J, Virgin HW. STAT1-dependent innate immunity to a Norwalk-like virus. Science (2003) 299:1575-8. doi:10.1126/ science. 1077905

89. Chachu KA, Strong DW, LoBue AD, Wobus CE, Baric RS, Virgin HW. Antibody is critical for the clearance of murine norovirus infection. J Virol (2008) 82:6610-7. doi:10.1128/JVI.00141-08

90. Chachu KA, LoBue AD, Strong DW, Baric RS, Virgin HW. Immune mechanisms responsible for vaccination against and clearance of mucosal and lymphatic norovirus infection. PLoS Pathog (2008) 4:e1000236. doi:10.1371/journal.ppat. 1000236

91. Tate JE, Burton AH, Boschi-Pinto C, Steele AD, Duque J, Parashar UD. 2008 Estimate of worldwide rotavirus-associated mortality in children younger than 5 years before the introduction of universal rotavirus vaccination programmes: a systematic review and meta-analysis. Lancet Infect Dis (2012) 12:136-41. doi:10.1016/S1473-3099(11)70253-5

92. Coulson BS, Grimwood K, Hudson IL, Barnes GL, Bishop RF. Role of coproantibody in clinical protection of children during reinfection with rotavirus. JClin Microbiol (1992) 30:1678-84.

93. Matson DO, O’Ryan ML, Herrera I, Pickering LK, Estes MK. Fecal antibody responses to symptomatic and asymptomatic rotavirus infections. J Infect Dis (1993) 167:577-83. doi:10.1093/infdis/167.3.577

94. O’Ryan ML, Matson DO, Estes MK, Pickering LK. Acquisition of serum isotype-specific and $\mathrm{G}$ type-specific antirotavirus antibodies among children in day care centers. Pediatr Infect Dis J (1994) 13:890-5. doi:10.1097/00006454199410000-00009

95. Offit PA. Correlates of protection against rotavirus infection and disease. Novartis Found Symp (2001) 238:106-13. doi:10.1002/0470846534.ch8

96. Johansen K, Svensson L. Neutralization of rotavirus and recognition of immunologically important epitopes on VP4 and VP7 by human IgA. Arch Virol (1997) 142:1491-8. doi:10.1007/s007050050175

97. McGhee JR, Lamm ME, Strober W. Mucosal immune responses: an overview In: Ogra PL, Mestecky J, Lamm ME, Strober W, Bienenstock J, McGhee JR, editors. Mucosal Immunology. San Diego: Academic Press (1999). p. 485-506.

98. Murphy K. Janeway's Immunobiology. New York: Garland Science Publishing (2011).

99. Berlin C, Berg EL, Briskin MJ, Andrew DP, Kilshaw PJ, Holzmann B, et al. Alpha 4 beta 7 integrin mediates lymphocyte binding to the mucosal vascular addressin MAdCAM-1. Cell (1993) 74:185-95. doi:10.1016/0092-8674(93) 90305-A

100. Farstad IN, Halstensen TS, Lazarovits AI, Norstein J, Fausa O, Brandtzaeg P. Human intestinal B-cell blasts and plasma cells express the mucosal homing receptor integrin alpha 4 beta 7. Scand J Immunol (1995) 42:662-72. doi:10.1111/j.1365-3083.1995.tb03709.x

101. Youngman KR, Franco MA, Kuklin NA, Rott LS, Butcher EC, Greenberg HB. Correlation of tissue distribution, developmental phenotype, and intestinal homing receptor expression of antigen-specific B cells during the murine antirotavirus immune response. J Immunol (2002) 168:2173-81.

102. Macpherson AJ, Gatto D, Sainsbury E, Harriman GR, Hengartner H, Zinkernagel RM. A primitive T cell-independent mechanism of intestinal mucosal IgA responses to commensal bacteria. Science (2000) 288:2222-6. doi:10.1126/ science.288.5474.2222

103. Bemark M, Boysen P, Lycke NY. Induction of gut IgA production through $\mathrm{T}$ cell-dependent and T cell-independent pathways. Ann N Y Acad Sci (2012) 1247:97-116. doi:10.1111/j.1749-6632.2011.06378.x
104. Macpherson AJ, Geuking MB, McCoy KD. Immune responses that adapt the intestinal mucosa to commensal intestinal bacteria. Immunology (2005) 115:153-62. doi:10.1111/j.1365-2567.2005.02159.x

105. Macpherson AJ, Hunziker L, McCoy K, Lamarre A. IgA responses in the intestinal mucosa against pathogenic and non-pathogenic microorganisms. Microbes Infect (2001) 3:1021-35. doi:10.1016/S1286-4579(01)01460-5

106. Bergqvist P, Gardby E, Stensson A, Bemark M, Lycke NY. Gut IgA class switch recombination in the absence of CD40 does not occur in the lamina propria and is independent of germinal centers. J Immunol (2006) 177: 7772-83.

107. Blutt SE, Warfield KL, Estes MK, Conner ME. Differential requirements for T cells in viruslike particle- and rotavirus-induced protective immunity. J Virol (2008) 82:3135-8. doi:10.1128/JVI.01727-07

108. Stavnezer J. Antibody class switching. Adv Immunol (1996) 61:79-146. doi:10. 1016/S0065-2776(08)60866-4

109. Mond JJ, Lees A, Snapper CM. T cell-independent antigens type 2. Annu Rev Immunol (1995) 13:655-92. doi:10.1146/annurev.iy.13.040195.003255

110. Szomolanyi-Tsuda E, Welsh RM. T-cell-independent antiviral antibody responses. Curr Opin Immunol (1998) 10:431-5. doi:10.1016/S0952-7915(98) 80117-9

111. Cyster JG. B cells on the front line. Nat Immunol (2000) 1:9-10. doi:10.1038/ 35036032

112. Fagarasan S, Honjo T. T-independent immune response: new aspects of B cell biology. Science (2000) 290:89-92. doi:10.1126/science.290.5489.89

113. Charan S, Zinkernagel RM. Antibody mediated suppression of secondary IgM response in nude mice against vesicular stomatitis virus. J Immunol (1986) 136:3057-61.

114. Freer G, Burkhart C, Ciernik I, Bachmann MF, Hengartner H, Zinkernagel RM. Vesicular stomatitis virus Indiana glycoprotein as a T-cell-dependent and -independent antigen. J Virol (1994) 68:3650-5.

115. Mozdzanowska K, Furchner M, Zharikova D, Feng J, Gerhard W. Roles of CD4+ T-cell-independent and -dependent antibody responses in the control of influenza virus infection: evidence for noncognate CD4+ T-cell activities that enhance the therapeutic activity of antiviral antibodies. J Virol (2005) 79:5943-51. doi:10.1128/JVI.79.10.5943-5951.2005

116. Lee BO, Rangel-Moreno J, Moyron-Quiroz JE, Hartson L, Makris M, Sprague $\mathrm{F}$, et al. CD4 T cell-independent antibody response promotes resolution of primary influenza infection and helps to prevent reinfection. J Immunol (2005) 175:5827-38.

117. Szomolanyi-Tsuda E, Welsh RM. Judging a virus by its cover. J Clin Invest (2004) 114:895-7. doi:10.1172/JCI23098

118. Franco MA, Greenberg HB. Immunity to rotavirus in T cell deficient mice. Virology (1997) 238:169-79. doi:10.1006/viro.1997.8843

119. Eiden J, Lederman HM, Vonderfecht S, Yolken R. T-cell-deficient mice display normal recovery from experimental rotavirus infection. J Virol (1986) 57:706-8.

120. Cosgrove D, Gray D, Dierich A, Kaufman J, Lemeur M, Benoist C, et al. Mice lacking MHC class II molecules. Cell (1991) 66:1051-66. doi:10.1016/00928674(91)90448-8

121. Xu J, Foy TM, Laman JD, Elliott EA, Dunn JJ, Waldschmidt TJ, et al. Mice deficient for the CD40 ligand. Immunity (1994) 1:423-31. doi:10.1016/10747613(94)90073-6

122. Renshaw BR, Fanslow WC III, Armitage RJ, Campbell KA, Liggitt D, Wright B, et al. Humoral immune responses in CD40 ligand-deficient mice. J Exp Med (1994) 180:1889-900. doi:10.1084/jem.180.5.1889

123. von Bulow GU, van Deursen JM, Bram RJ. Regulation of the T-independent humoral response by TACI. Immunity (2001) 14:573-82. doi:10.1016/S10747613(01)00130-3

124. Shulga-Morskaya S, Dobles M, Walsh ME, Ng LG, MacKay F, Rao SP, et al. B cell-activating factor belonging to the TNF family acts through separate receptors to support B cell survival and $\mathrm{T}$ cell-independent antibody formation. J Immunol (2004) 173:2331-41.

125. Litinskiy MB, Nardelli B, Hilbert DM, He B, Schaffer A, Casali P, et al. DCs induce CD40-independent immunoglobulin class switching through BLyS and APRIL. Nat Immunol (2002) 3:822-9. doi:10.1038/ni829

126. Castigli E, Scott S, Dedeoglu F, Bryce P, Jabara H, Bhan AK, et al. Impaired IgA class switching in APRIL-deficient mice. Proc Natl Acad Sci U S A (2004) 101:3903-8. doi:10.1073/pnas.0307348101 
127. Cerutti A, Cols M, Puga I. Activation of B cells by non-canonical helper signals. EMBO Rep (2012) 13:798-810. doi:10.1038/embor.2012.111

128. Bishop RF, Davidson GP, Holmes IH, Ruck BJ. Virus particles in epithelial cells of duodenal mucosa from children with acute non-bacterial gastroenteritis. Lancet (1973) 2:1281-3. doi:10.1016/S0140-6736(73)92867-5

129. Middleton PJ, Petric M, Szymanski MT. Propagation of infantile gastroenteritis virus (orbi-group) in conventional and germfree piglets. Infect Immun (1975) 12:1276-80.

130. Mebus CA, Wyatt RG, Kapikian AZ. Intestinal lesions induced in gnotobiotic calves by the virus of human infantile gastroenteritis. Vet Pathol (1977) 14:273-82. doi:10.1177/030098587701400310

131. Coelho KI, Bryden AS, Hall C, Flewett TH. Pathology of rotavirus infection in suckling mice: a study by conventional histology, immunofluorescence, ultrathin sections, and scanning electron microscopy. Ultrastruct Pathol (1981) 2:59-80. doi:10.3109/01913128109031504

132. Ward RL, McNeal MM, Sheridan JF. Development of an adult mouse model for studies on protection against rotavirus. J Virol (1990) 64:5070-5.

133. Sheridan JF, Eydelloth RS, Vonderfecht SL, Aurelian L. Virus-specific immunity in neonatal and adult mouse rotavirus infection. Infect Immun (1983) 39:917-27.

134. Kraft LM. Observations on the control and natural history of epidemic diarrhea of infant mice (EDIM). Yale J Biol Med (1958) 31:122-36.

135. Conner ME, Darlington RW. Rotavirus infection in foals. Am J Vet Res (1980) 41:1699-703.

136. Saif L, Yuan L, Ward L, To T. Comparative studies of the pathogenesis, antibody immune responses, and homologous protection to porcine and human rotaviruses in gnotobiotic piglets. Adv Exp Med Biol (1997) 412:397-403. doi:10.1007/978-1-4899-1828-4_62

137. To TL, Ward LA, Yuan L, Saif LJ. Serum and intestinal isotype antibody responses and correlates of protective immunity to human rotavirus in a gnotobiotic pig model of disease. J Gen Virol (1998) 79(Pt 11):2661-72.

138. Ward LA, Yuan L, Rosen BI, To TL, Saif LJ. Development of mucosal and systemic lymphoproliferative responses and protective immunity to human group A rotaviruses in a gnotobiotic pig model. Clin Diagn Lab Immunol (1996) 3:342-50.

139. Feng N, Burns JW, Bracy L, Greenberg HB. Comparison of mucosal and systemic humoral immune responses and subsequent protection in mice orally inoculated with a homologous or a heterologous rotavirus. J Virol (1994) 68:7766-73.

140. Franco MA, Greenberg HB. Role of B cells and cytotoxic T lymphocytes in clearance of and immunity to rotavirus infection in mice. J Virol (1995) 69:7800-6.

141. Crawford SE, Patel DG, Cheng E, Berkova Z, Hyser JM, Ciarlet M, et al. Rotavirus viremia and extraintestinal viral infection in the neonatal rat model. J Virol (2006) 80:4820-32. doi:10.1128/JVI.80.10.4820-4832.2006

142. Bruce MG, Campbell IC, van Pinxteren L, Snodgrass DR. Intestinal cellular immunity after primary rotavirus infection. J Comp Pathol (1995) 113:155-64. doi:10.1016/S0021-9975(05)80030-1

143. van Pinxteren LA, Bruce MG, Campbell I, Clarke CJ, Snodgrass DR. Characterisation of the primary local and systemic immune response in gnotobiotic lambs against rotavirus infection. Vet Immunol Immunopathol (1998) 64:349-65. doi:10.1016/S0165-2427(98)00168-8

144. Van Zaane D, Ijzerman J, De Leeuw PW. Intestinal antibody response after vaccination and infection with rotavirus of calves fed colostrum with or without rotavirus antibody. Vet Immunol Immunopathol (1986) 11:45-63. doi:10.1016/0165-2427(86)90087-5

145. Vonderfecht SL, Osburn BI. Immunity to rotavirus in conventional neonatal calves. J Clin Microbiol (1982) 16:935-42.

146. Conner ME, Gilger MA, Estes MK, Graham DY. Serologic and mucosal immune response to rotavirus infection in the rabbit model. J Virol (1991) 65:2562-71.

147. Conner ME, Estes MK, Graham DY. Rabbit model of rotavirus infection. J Virol (1988) 62:1625-33.

148. Ciarlet M, Gilger MA, Barone C, McArthur M, Estes MK, Conner ME. Rotavirus disease, but not infection and development of intestinal histopathological lesions, is age restricted in rabbits. Virology (1998) 251:343-60. doi:10.1006/ viro.1998.9406

149. Conner ME, Graham DY, Estes MK. Determination of the duration of a primary immune response and the ID50 of ALA rabbit rotavirus in rabbits. Arch Virol (1997) 142:2281-94. doi:10.1007/s007050050242
150. Blutt SE, Kirkwood CD, Parreno V, Warfield KL, Ciarlet M, Estes MK, et al. Rotavirus antigenaemia and viraemia: a common event? Lancet (2003) 362:1445-9. doi:10.1016/S0140-6736(03)14687-9

151. Burns JW, Krishnaney AA, Vo PT, Rouse RV, Anderson LJ, Greenberg HB. Analyses of homologous rotavirus infection in the mouse model. Virology (1995) 207:143-53. doi:10.1006/viro.1995.1060

152. McNeal MM, Belli J, Basu M, Choi AH, Ward RL. Discovery of a new strain of murine rotavirus that is consistently shed in large quantities after oral inoculation of adult mice. Virology (2004) 320:1-11. doi:10.1016/j.virol. 2003.11.020

153. Blutt SE, Warfield KL, O’Neal CM, Estes MK, Conner ME. Host, viral, and vaccine factors that determine protective efficacy induced by rotavirus and virus-like particles (VLPs). Vaccine (2006) 24:1170-9. doi:10.1016/j.vaccine. 2005.08.090

154. Blutt SE, Fenaux M, Warfield KL, Greenberg HB, Conner ME. Active viremia in rotavirus-infected mice. J Virol (2006) 80:6702-5. doi:10.1128/JVI.00329-06

155. McNeal MM, Ward RL. Long-term production of rotavirus antibody and protection against reinfection following a single infection of neonatal mice with murine rotavirus. Virology (1995) 211:474-80. doi:10.1006/viro.1995.1429

156. Offit PA, Clark HF. Protection against rotavirus-induced gastroenteritis in a murine model by passively acquired gastrointestinal but not circulating antibodies. J Virol (1985) 54:58-64.

157. Snodgrass DR, Wells PW. The immunoprophylaxis of rotavirus infections in lambs. Vet Rec (1978) 102:146-8. doi:10.1136/vr.102.7.146

158. Snodgrass DR, Wells PW. Rotavirus infection in lambs: studies on passive protection. Arch Virol (1976) 52:201-5. doi:10.1007/BF01348017

159. Matsui SM, Offit PA, Vo PT, Mackow ER, Benfield DA, Shaw RD, et al. Passive protection against rotavirus-induced diarrhea by monoclonal antibodies to the heterotypic neutralization domain of VP7 and the VP8 fragment of VP4. JClin Microbiol (1989) 27:780-2.

160. Burns JW, Siadat-Pajouh M, Krishnaney AA, Greenberg HB. Protective effect of rotavirus VP6-specific IgA monoclonal antibodies that lack neutralizing activity. Science (1996) 272:104-7. doi:10.1126/science.272.5258.104

161. Feng N, Lawton JA, Gilbert J, Kuklin N, Vo P, Prasad BV, et al. Inhibition of rotavirus replication by a non-neutralizing, rotavirus VP6-specific IgA mAb. J Clin Invest (2002) 109:1203-13. doi:10.1172/JCI200214397

162. Corthesy B, Benureau Y, Perrier C, Fourgeux C, Parez N, Greenberg H, et al. Rotavirus anti-VP6 secretory immunoglobulin A contributes to protection via intracellular neutralization but not via immune exclusion. J Virol (2006) 80:10692-9. doi:10.1128/JVI.00927-06

163. Davidson GP, Whyte PB, Daniels E, Franklin K, Nunan H, McCloud PI, et al. Passive immunisation of children with bovine colostrum containing antibodies to human rotavirus. Lancet (1989) 2:709-12. doi:10.1016/S0140-6736(89) 90771-X

164. Barnes GL, Doyle LW, Hewson PH, Knoches AM, McLellan JA, Kitchen WH, et al. A randomised trial of oral gammaglobulin in low-birth-weight infants infected with rotavirus. Lancet (1982) 1:1371-3. doi:10.1016/S0140-6736(82) 92496-5

165. Ebina T, Sato A, Umezu K, Ishida N, Ohyama S, Oizumi A, et al. Prevention of rotavirus infection by oral administration of cow colostrum containing antihumanrotavirus antibody. Med Microbiol Immunol (1985) 174:177-85. doi:10.1007/BF02123694

166. Turner RB, Kelsey DK. Passive immunization for prevention of rotavirus illness in healthy infants. Pediatr Infect Dis J (1993) 12:718-22. doi:10.1097/ 00006454-199309000-00003

167. Glass RI, Stoll BJ, Wyatt RG, Hoshino Y, Banu H, Kapikian AZ. Observations questioning a protective role for breast-feeding in severe rotavirus diarrhea. Acta Paediatr Scand (1986) 75:713-8. doi:10.1111/j.1651-2227.1986.tb10279.x

168. Glass RI, Stoll BJ. The protective effect of human milk against diarrhea. A review of studies from Bangladesh. Acta Paediatr Scand Suppl (1989) 351:131-6. doi:10.1111/j.1651-2227.1989.tb11225.x

169. Blake PA, Ramos S, MacDonald KL, Rassi V, Gomes TA, Ivey C, et al. Pathogen-specific risk factors and protective factors for acute diarrheal disease in urban Brazilian infants. J Infect Dis (1993) 167:627-32. doi:10.1093/ infdis/167.3.627

170. Clemens J, Rao M, Ahmed F, Ward R, Huda S, Chakraborty J, et al. Breastfeeding and the risk of life-threatening rotavirus diarrhea: prevention or postponement? Pediatrics (1993) 92:680-5. 
171. Henry FJ, Bartholomew RK. Epidemiology and transmission of rotavirus infections and diarrhoea in St. Lucia, West Indies. West Indian Med J (1990) 39:205-12.

172. Coffin SE, Klinek M, Offit PA. Induction of virus-specific antibody production by lamina propria lymphocytes following intramuscular inoculation with rotavirus. J Infect Dis (1995) 172:874-8. doi:10.1093/infdis/172.3.874

173. Coffin SE, Offit PA. Induction of mucosal B-cell memory by intramuscular inoculation of mice with rotavirus. J Virol (1998) 72:3479-83.

174. Yuan L, Ward LA, Rosen BI, To TL, Saif LJ. Systematic and intestinal antibodysecreting cell responses and correlates of protective immunity to human rotavirus in a gnotobiotic pig model of disease. J Virol (1996) 70:3075-83.

175. Williams MB, Butcher EC. Homing of naive and memory T lymphocyte subsets to Peyer's patches, lymph nodes, and spleen. J Immunol (1997) 159:1746-52.

176. Jeannin P, Herbault N, Delneste Y, Magistrelli G, Lecoanet-Henchoz S, Caron $\mathrm{G}$, et al. Human effector memory T cells express CD86: a functional role in naive T cell priming. J Immunol (1999) 162:2044-8.

177. McNeal MM, Broome RL, Ward RL. Active immunity against rotavirus infection in mice is correlated with viral replication and titers of serum rotavirus IgA following vaccination. Virology (1994) 204:642-50. doi:10.1006/viro.1994. 1579

178. McNeal MM, Rae MN, Ward RL. Antibody responses and protection stimulated by sequential oral-parenteral immunization of mice with rotavirus. Vaccine (1999) 17:639-45. doi:10.1016/S0264-410X(98)00244-8

179. McNeal MM, Stone SC, Basu M, Bean JA, Clements JD, Hendrickson BA, et al. Protection against rotavirus shedding after intranasal immunization of mice with a chimeric VP6 protein does not require intestinal IgA. Virology (2006) 346:338-47. doi:10.1016/j.virol.2005.11.016

180. O’Neal CM, Clements JD, Estes MK, Conner ME. Rotavirus 2/6-VLPs administered intranasally with cholera toxin, E. coli heat-labile toxin and LT-R192G induce protection from rotavirus challenge. J Virol (1998) 72:3390-3.

181. Bertolotti-Ciarlet A, Ciarlet M, Crawford SE, Conner ME, Estes MK. Immunogenicity and protective efficacy of rotavirus 2/6-virus-like particles produced by a dual baculovirus expression vector and administered intramuscularly, intranasally, or orally to mice. Vaccine (2003) 21:3885-900. doi:10.1016/S0264410X(03)00308-6

182. Jiang B, Estes MK, Barone C, Barniak V, O’Neal CM, Ottaiano A, et al. Heterotypic protection from rotavirus infection in mice vaccinated with virus-like particles. Vaccine (1999) 17:1005-13. doi:10.1016/S0264-410X(98)00317-X

183. Ciarlet M, Crawford SE, Barone C, Bertolotti-Ciarlet A, Ramig RF, Estes MK et al. Subunit rotavirus vaccine administered parenterally to rabbits induces active protective immunity. J Virol (1998) 72:9233-46.

184. Conner ME, Crawford SE, Barone C, Estes MK. Rotavirus vaccine administered parenterally induces protective immunity. J Virol (1993) 67:6633-41.

185. Agnello D, Herve CA, Lavaux A, Darniot M, Guillon P, Charpilienne A, et al. Intrarectal immunization with rotavirus $2 / 6$ virus-like particles induces an antirotavirus immune response localized in the intestinal mucosa and protects against rotavirus infection in mice. J Virol (2006) 80:3823-32. doi:10.1128/JVI. 80.8.3823-3832.2006

186. Gonzalez R, Franco M, Sarmiento L, Romero M, Schael IP. Serum IgA levels induced by rotavirus natural infection, but not following immunization with the RRV-TV vaccine (Rotashield), correlate with protection. J Med Virol (2005) 76:608-12. doi:10.1002/jmv.20404

187. Ward RL, Bernstein DI. Lack of correlation between serum rotavirus antibody titers and protection following vaccination with reassortant RRV vaccines. US Rotavirus Vaccine Efficacy Group. Vaccine (1995) 13:1226-32.

188. Vesikari T, Matson DO, Dennehy P, Van Damme P, Santosham M, Rodriguez Z, et al. Safety and efficacy of a pentavalent human-bovine (WC3) reassortant rotavirus vaccine. $N$ Engl J Med (2006) 354:23-33. doi:10.1056/ NEJMoa052664

189. Ruiz-Palacios GM, Perez-Schael I, Velazquez FR, Abate H, Breuer T, Clemens SC, et al. Safety and efficacy of an attenuated vaccine against severe rotavirus gastroenteritis. N Engl J Med (2006) 354:11-22. doi:10.1056/ NEJMoa052434

190. De Oliveira LH, Giglio N, Ciapponi A, Garcia MS, Kuperman M, Sanwogou NJ, et al. Temporal trends in diarrhea-related hospitalizations and deaths in children under age 5 before and after the introduction of the rotavirus vaccine in four Latin American countries. Vaccine (2013) 31(Suppl 3):C99-108. doi:10.1016/j.vaccine.2013.05.065
191. Pendleton A, Galic M, Clarke C, Ng SP, Ledesma E, Ramakrishnan G, et al Impact of rotavirus vaccination in Australian children below 5 years of age: a database study. Hum Vaccin Immunother (2013) 9(8):1617-25. doi:10.4161/hv. 24831

192. Kilgore A, Donauer S, Edwards KM, Weinberg GA, Payne DC, Szilagyi PG, et al. Rotavirus-associated hospitalization and emergency department costs and rotavirus vaccine program impact. Vaccine (2013) 31:4164-71. doi:10.1016/j.vaccine.2013.06.085

193. Patel M, Glass RI, Jiang B, Santosham M, Lopman B, Parashar U. A systematic review of anti-rotavirus serum IgA antibody titer as a potential correlate of rotavirus vaccine efficacy. J Infect Dis (2013) 208:284-94. doi:10.1093/infdis/ jit166

194. Marcelin G, Miller AD, Blutt SE, Conner ME. Immune mediators of rotavirus antigenemia clearance in mice. J Virol (2011) 85:7937-41. doi:10.1128/JVI 00844- 10

195. McNeal MM, Rae MN, Ward RL. Evidence that resolution of rotavirus infection in mice is due to both CD4 and CD8 cell-dependent activities. J Virol (1997) 71:8735-42.

196. VanCott JL, McNeal MM, Flint J, Bailey SA, Choi AH, Ward RL. Role for T cell-independent $\mathrm{B}$ cell activity in the resolution of primary rotavirus infection in mice. Eur J Immunol (2001) 31:3380-7. doi:10.1002/1521-4141(200111)31: $11<3380:$ :AID-IMMU3380>3.0.CO;2-0

197. Blutt SE, Miller AD, Salmon SL, Metzger DW, Conner ME. IgA is important for clearance and critical for protection from rotavirus infection. Mucosal Immunol (2012) 5:712-9. doi:10.1038/mi.2012.51

198. Williams MB, Rose JR, Rott LS, Franco MA, Greenberg HB, Butcher EC. The memory B cell subset responsible for the secretory IgA response and protective humoral immunity to rotavirus expresses the intestinal homing receptor, alpha4beta7. J Immunol (1998) 161:4227-35.

199. Feng N, Jaimes MC, Lazarus NH, Monak D, Zhang C, Butcher EC, et al. Redundant role of chemokines CCL25/TECK and CCL28/MEC in IgA+ plasmablast recruitment to the intestinal lamina propria after rotavirus infection. JImmunol (2006) 176:5749-59.

200. Yuan L, Geyer A, Saif LJ. Short-term immunoglobulin A B-cell memory resides in intestinal lymphoid tissues but not in bone marrow of gnotobiotic pigs inoculated with Wa human rotavirus. Immunology (2001) 103:188-98. doi:10.1046/j.1365-2567.2001.01229.x

201. Kushnir N, Bos NA, Zuercher AW, Coffin SE, Moser CA, Offit PA, et al. B2 but not B1 cells can contribute to CD4+ T-cell-mediated clearance of rotavirus in SCID mice. J Virol (2001) 75:5482-90. doi:10.1128/JVI.75.12.5482-5490.2001

202. Cebra JJ, Gearhart PJ, Kamat R, Robertson SM, Tseng J. Origin and differentiation of lymphocytes involved in the secretory IgA responses. Cold Spring Harb Symp Quant Biol (1977) 41(Pt 1):201-15. doi:10.1101/SQB.1977.041.01. 026

203. De Togni P, Goellner J, Ruddle NH, Streeter PR, Fick A, Mariathasan S, et al Abnormal development of peripheral lymphoid organs in mice deficient in lymphotoxin. Science (1994) 264:703-7. doi:10.1126/science.8171322

204. Lopatin U, Blutt SE, Conner ME, Kelsall BL. Lymphotoxin alpha-deficient mice clear persistent rotavirus infection after local generation of mucosal IgA. J Virol (2012) 87(1):524-30. doi:10.1128/JVI.01801-12

205. Blutt SE, Warfield KL, Lewis DE, Conner ME. Early response to rotavirus infection involves massive B cell activation. J Immunol (2002) 168:5716-21.

206. Deal EM, Lahl K, Narvaez CF, Butcher EC, Greenberg HB. Plasmacytoid dendritic cells promote rotavirus-induced human and murine B cell responses. J Clin Invest (2013) 123:2464-74. doi:10.1172/JCI60945

207. Ramig RF. Pathogenesis of intestinal and systemic rotavirus infection. J Virol (2004) 78:10213-20. doi:10.1128/JVI.78.19.10213-10220.2004

208. VanCott JL, Franco MA, Greenberg HB, Sabbaj S, Tang B, Murray R, et al. Protective immunity to rotavirus shedding in the absence of interleukin-6: Th1 cells and immunoglobulin A develop normally. J Virol (2000) 74:5250-6. doi:10.1128/JVI.74.11.5250-5256.2000

209. Schneider P, MacKay F, Steiner V, Hofmann K, Bodmer JL, Holler N, et al. BAFF, a novel ligand of the tumor necrosis factor family, stimulates B cell growth. J Exp Med (1999) 189:1747-56. doi:10.1084/jem.189.11.1747

210. Cook DN, Prosser DM, Forster R, Zhang J, Kuklin NA, Abbondanzo SJ, et al. CCR6 mediates dendritic cell localization, lymphocyte homeostasis, and immune responses in mucosal tissue. Immunity (2000) 12:495-503. doi:10.1016/S1074-7613(00)80201-0 
211. Lopez-Guerrero DV, Meza-Perez S, Ramirez-Pliego O, Santana-Calderon MA, Espino-Solis P, Gutierrez-Xicotencatl L, et al. Rotavirus infection activates dendritic cells from Peyer's patches in adult mice. J Virol (2010) 84:1856-66. doi:10.1128/JVI.02640-08

212. Weitkamp JH, Kallewaard N, Kusuhara K, Bures E, Williams JV, LaFleur B, et al. Infant and adult human B cell responses to rotavirus share common immunodominant variable gene repertoires. J Immunol (2003) 171:4680-8.

213. Weitkamp JH, Lafleur BJ, Crowe JE Jr. Rotavirus-specific CD5+ B cells in young children exhibit a distinct antibody repertoire compared with CD5- B cells. Hum Immunol (2006) 67:33-42. doi:10.1016/j.humimm.2006.02.024

214. Weitkamp JH, Kallewaard NL, Bowen AL, Lafleur BJ, Greenberg HB, Crowe JE Jr. VH1-46 is the dominant immunoglobulin heavy chain gene segment in rotavirus-specific memory $\mathrm{B}$ cells expressing the intestinal homing receptor alpha4beta7. J Immunol (2005) 174:3454-60.

215. Lindner C, Wahl B, Fohse L, Suerbaum S, Macpherson AJ, Prinz I, et al. Age, microbiota, and $\mathrm{T}$ cells shape diverse individual IgA repertoires in the intestine. J Exp Med (2012) 209:365-77. doi:10.1084/jem.20111980

216. Grimwood K, Lund JC, Coulson BS, Hudson IL, Bishop RF, Barnes GL. Comparison of serum and mucosal antibody responses following severe acute rotavirus gastroenteritis in young children. J Clin Microbiol (1988) 26:732-8.

217. Yamaguchi H, Inouye S, Yamauchi M, Morishima T, Matsuno S, Isomura S, et al. Anamnestic response in fecal IgA antibody production after rotaviral infection of infants. J Infect Dis (1985) 152:398-400. doi:10.1093/infdis/152.2.398

218. Hjelt K, Grauballe PC, Andersen L, Schiotz PO, Howitz P, Krasilnikoff PA. Antibody response in serum and intestine in children up to six months after a naturally acquired rotavirus gastroenteritis. J Pediatr Gastroenterol Nutr (1986) 5:74-80. doi:10.1097/00005176-198601000-00014

219. Yoshida T, Mei H, Dorner T, Hiepe F, Radbruch A, Fillatreau S, et al. Memory B and memory plasma cells. Immunol Rev (2010) 237:117-39. doi:10.1111/j. 1600-065X.2010.00938.x
220. Franco MA, Greenberg HB. Immunity to homologous rotavirus infection in adult mice. Trends Microbiol (2000) 8:50-2. doi:10.1016/S0966-842X(99) 01682-0

221. Smith KG, Hewitson TD, Nossal GJ, Tarlinton DM. The phenotype and fate of the antibody-forming cells of the splenic foci. Eur J Immunol (1996) 26:444-8. doi:10.1002/eji.1830260226

222. Slifka MK, Antia R, Whitmire JK, Ahmed R. Humoral immunity due to longlived plasma cells. Immunity (1998) 8:363-72. doi:10.1016/S1074-7613(00) 80541-5

223. Brown KA, Offit PA. Rotavirus-specific proteins are detected in murine macrophages in both intestinal and extraintestinal lymphoid tissues. Microb Pathog (1998) 24:327-31. doi:10.1006/mpat.1997.0198

Conflict of Interest Statement: The authors declare that the research was conducted in the absence of any commercial or financial relationships that could be construed as a potential conflict of interest.

Received: 21 May 2013; paper pending published: 07 June 2013; accepted: 08 November 2013; published online: 28 November 2013.

Citation: Blutt SE and Conner ME (2013) The gastrointestinal frontier: IgA and viruses. Front. Immunol. 4:402. doi: 10.3389/fimmu.2013.00402

This article was submitted to Mucosal Immunity, a section of the journal Frontiers in Immunology.

Copyright (c) 2013 Blutt and Conner. This is an open-access article distributed under the terms of the Creative Commons Attribution License (CC BY). The use, distribution or reproduction in other forums is permitted, provided the original author(s) or licensor are credited and that the original publication in this journal is cited, in accordance with accepted academic practice. No use, distribution or reproduction is permitted which does not comply with these terms. 